Nevada

Environmental

Restoration

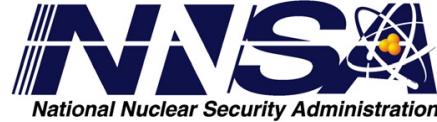

Project

\title{
Addendum to the Closure Report for Corrective Action Unit 214: Bunkers and Storage Areas Nevada Test Site, Nevada
}

Controlled Copy No.:

Revision No.: 0

October 2008

Approved for public release; further dissemination unlimited.

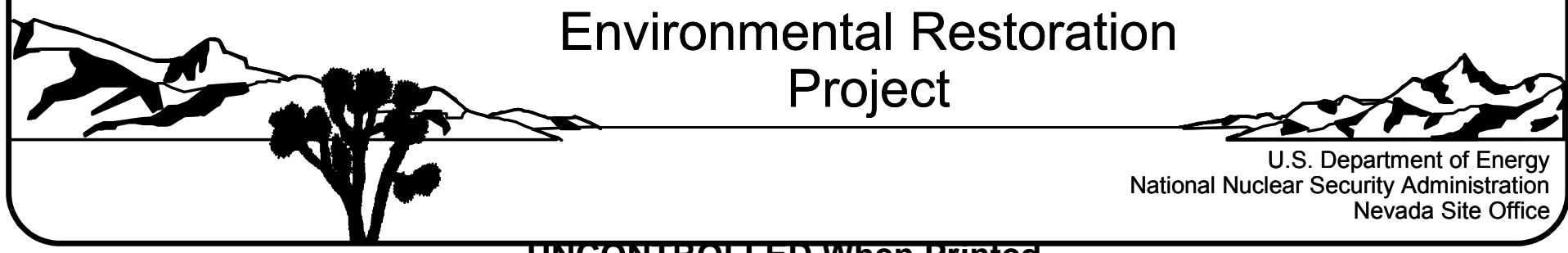


Available for public sale, in paper, from:

U.S. Department of Commerce

National Technical Information Service

5285 Port Royal Road

Springfield, VA 22161

Phone: 800.553 .6847

Fax: 703.605.6900

Email: orders@ntis.gov

Online ordering: http://www.ntis.gov/ordering.htm

Available electronically at $\underline{h t p: / / w w w . o s t i . g o v / b r i d g e ~}$

Available for a processing fee to U.S. Department of Energy and its contractors, in paper, from:

U.S. Department of Energy

Office of Scientific and Technical Information

P.O. Box 62

Oak Ridge, TN 37831-0062

Phone: 865.576 .8401

Fax: 865.576.5728

Email: reports@adonis.osti.gov

Reference herein to any specific commercial product, process, or service by trade name, trademark, manufacturer, or otherwise, does not necessarily constitute or imply its endorsement, recommendation, or favoring by the United States Government or any agency thereof or its contractors or subcontractors. 


\title{
ADDENDUM TO THE CLOSURE REPORT FOR CORRECTIVE ACTION UNIT 214: BUNKERS AND STORAGE AREAS NEVADA TEST SITE, NEVADA
}

\author{
U.S. Department of Energy \\ National Nuclear Security Administration \\ Nevada Site Office \\ Las Vegas, Nevada
}

Controlled Copy No.:

Revision No.: 0

October 2008

Approved for public release; further dissemination unlimited. 


\section{Addendum to the Closure Report for Removal of the Use Restriction}

This document constitutes an addendum to the September 2006, Closure Report for Corrective Action Unit 214: Bunkers and Storage Areas as described in the document Recommendations and Justifications for Modifications for Use Restrictions Established under the U.S. Department of Energy, National Nuclear Security Administration Nevada Site Office Federal Facility Agreement and Consent Order (UR Modification document) dated February 2008. The UR Modification document was approved by NDEP on February 26, 2008. The approval of the UR Modification document constituted approval of each of the recommended UR modifications. In conformance with the UR Modification document, this addendum consists of:

- This cover page that refers the reader to the UR Modification document for additional information

- The cover and signature pages of the UR Modification document

- The NDEP approval letter

- The corresponding section of the UR Modification document

This addendum provides the documentation justifying the cancellation of the URs for:

- CAS 25-23-01, Contaminated Materials

- CAS 25-23-19, Radioactive Material Storage

These URs were established as part of Federal Facility Agreement and Consent Order (FFACO) corrective actions and were based on the presence of contaminants at concentrations greater than the action levels established at the time of the initial investigation (FFACO, 1996; as amended August 2006).

Since these URs were established, practices and procedures relating to the implementation of risk-based corrective actions (RBCA) have changed. Therefore, these URs were re-evaluated against the current RBCA criteria as defined in the Industrial Sites Project Establishment of Final Action Levels (NNSA/NSO, 2006c). This re-evaluation consisted of comparing the original data (used to define the need for the URs) to risk-based final action levels (FALs) developed using the current Industrial Sites RBCA process.

The re-evaluation resulted in a recommendation to remove these URs because contamination is not present at these sites above the risk-based FALs. Requirements for inspecting and maintaining these URs will be canceled, and the postings and signage at each site will be removed. Fencing and posting may be present at these sites that are unrelated to the FFACO URs such as for radiological control purposes as required by the NV/YMP Radiological Control Manual (NNSA/NSO, 2004f). This modification will not affect or modify any non-FFACO requirements for fencing, posting, or monitoring at these sites. 
Nevada

Environmental

Restoration

Project

Recommendations and Justifications for Modifications for Use Restrictions Established under the U.S. Department of Energy, National Nuclear Security Administration Nevada Site Office

Federal Facility Agreement and Consent Order

Controlled Copy No.:

Revision No.: 0

February 2008

Approved for public release; further dissemination unlimited.

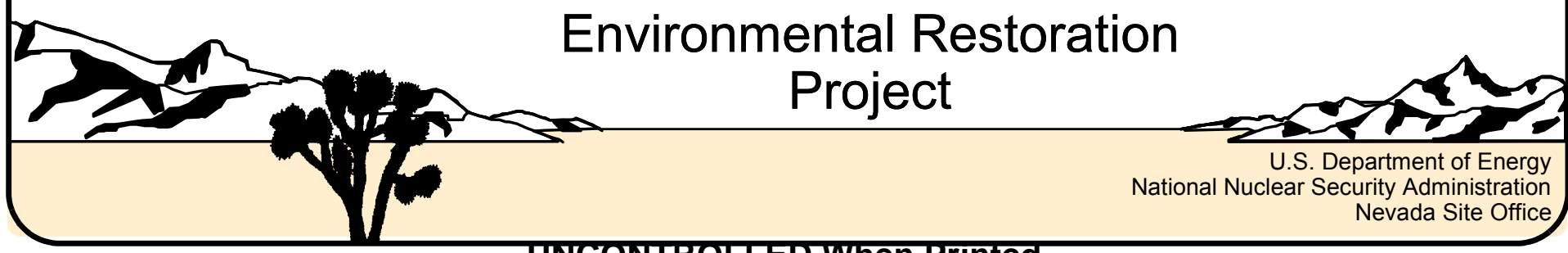


Recommendations and Justifications for Modifications for Use Restrictions Established under the U.S. Department of Energy, National Nuclear Security Administration Nevada Site Office Federal Facility Agreement and Consent Order

Approved by: /s/ Kevin J. Cabble

Date: $02 / 05 / 2008$

Kevin J. Cabble

Federal Sub-Project Director

Industrial Sites Sub-Project

Approved by:

/s/ John B. Jones

Date: $02 / 04 / 2008$

John B. Jones

Acting Federal Project Director

Environmental Restoration Project 
February 26, 2008

John B. Jones

Acting Federal Project Director

Environmental Restoration Project

National Nuclear Security Administration

Nevada Site Office

P. O. Box 98518

Las Vegas, NV 89193-8518

RE: Approval of Recommendations and Justifications for Modifications for Use Restrictions

Established under the U.S. Department of Energy, National Nuclear Security Administration, Nevada Site Office Federal Facility Agreement and Consent Order

Dear Mr. Jones:

The Nevada Division of Environmental Protection, Bureau of Federal Facilities (NDEP) staff has received and reviewed the February 2008 final report for Recommendations and Justifications for Modifications for Use Restrictions Established under the U.S. Department of Energy, National Nuclear Security Administration, Nevada Site Office. The NDEP approves the requested changes to the previously agreed upon use restrictions for those Corrective Action Sites (CASs) as described in the report.

Address any questions regarding this matter to either Ted Zaferatos at (702) 486-2850, ext. 234 , or me at (702) 486-2850, ext. 231.

Sincerely

\section{/s/ Tim Murphy}

\section{T.H. Murphy}

Chief

Bureau of Federal Facilities

$\mathrm{TZ}$

cc: $\quad$ E.F. DiSanza, WMP, NNSA/NSO

FFACO Group, PSG, NNSAINSO, Las Vegas, NV

David C. Loewer, DTRAVCXT1, M/S 645, Mercury, NV

W.R. Griffin, SNJV/DTRA, M/S 645, Mercury, NV

T.A. Thiele, NSTec, Las Vegas, NV

R.F. Boehlecke, SNJV, Las Vegas, NV

K. J. Cabble, ERP, NNSANSO, Las Vegas, NV

John Wong. Jeff MacDougall, Dennis Nicodemus, NDEP Las Vegas, NV 


\subsection{CAU 214, CAS 25-23-01 - Contaminated Materials, and CAS 25-23-19 - Radioactive Material Storage}

\subsection{CAS Descriptions}

Corrective Action Sites 25-23-01 and 25-23-19 are adjacent to each other and have similar historical backgrounds. They are located west of and adjacent to the Yucca Mountain Project - Sample Management Facility. The CASs were used for storage of radioactive equipment, hazardous waste, heavy equipment, reactor components, and drums and tanks of unspecified materials from 1982 to 1992. In 1995, the majority of materials were removed from the yards. Material remaining at the site as of 2004 included a large amount of steel equipment, one large furnace, large pieces of concrete and steel associated with the MX missile program, and several pallets of miscellaneous housekeeping debris (NNSA/NSO, 2004c). During closure activities, miscellaneous wood and metal debris - including metal framing, wooden pallets, and a dishwasher - were removed and disposed of as construction debris as a best management practice (BMP). Items deemed too large to remove were left in place (NNSA/NSO, 2006a).

\subsection{Current Use Restriction Description}

The future use of any land affected by these URs is restricted from any DOE or Air Force activity that may alter or modify the containment control, as approved by the state and identified in the CAU CR or other CAU documentation, unless appropriate concurrence is obtained in advance. Site monitoring requirements for the UR include periodic visual inspections of UR postings and fencing. These are required annually for the first five years, followed by every five years, for a total of 30 years (NNSA/NSO, 2006a).

\subsection{Basis for Current Use Restriction}

Samples were analyzed for TPH (DRO and GRO), total VOCs, total SVOCs, total RCRA metals, total beryllium, PCBs, isotopic $\mathrm{U}$, isotopic $\mathrm{Pu}, \mathrm{Sr}-90$, total pesticides, Toxicity Characteristic Leaching Procedure (TCLP) pesticides, total herbicides, TCLP herbicides, total chromium, hexavalent chromium, and gamma spectroscopy. Except for TPH-DRO, all other COPCs in the material remaining (following remediation) were detected below their PALs, including VOCs and SVOCs. Concentrations of TPH-DRO exceeding the PAL of $100 \mathrm{mg} / \mathrm{kg}$ were detected in 39 samples (NNSA/NSO, 2004c). 
Table 5-1 contains analytical results of all COCs at CASs 25-23-01 and 25-23-19 that are the basis for the current UR. The sample matrix for all samples is soil.

Table 5-1

Sample Results for COCs at CASs 25-23-01 and 25-23-19 Used To Establish Current Use Restriction

(Page 1 of 2)

\begin{tabular}{|c|c|c|c|c|}
\hline \multirow{2}{*}{ CAS } & \multirow{2}{*}{$\begin{array}{l}\text { Sample } \\
\text { Location }\end{array}$} & \multirow{2}{*}{$\begin{array}{c}\text { Sample } \\
\text { ID }\end{array}$} & \multirow{2}{*}{$\begin{array}{l}\text { Depth } \\
\text { (ft bgs) }\end{array}$} & \multirow{2}{*}{$\begin{array}{c}\text { TPH (DRO) } \\
\text { PAL } \\
100 \mathrm{mg} / \mathrm{kg}\end{array}$} \\
\hline & & & & \\
\hline \multirow{27}{*}{ 25-23-01 } & D01 & 214D002 & $0-0.5$ & $200(\mathrm{H}, \mathrm{Z})$ \\
\hline & D02 & 214D041 & $0-0.5$ & $220(\mathrm{H}, \mathrm{Z})$ \\
\hline & D06 & 214D039 & $0-0.5$ & $130(H, Z)$ \\
\hline & D07 & 214D009 & $0-0.5$ & $3,500(\mathrm{~J})$ \\
\hline & \multirow{2}{*}{ D10 } & 214D013 & $0-0.5$ & $2,800(\mathrm{H}, \mathrm{Z})$ \\
\hline & & 214D077 & $3.5-4.0$ & $200(Z)$ \\
\hline & D11 & 214D004 & $0-0.5$ & $170(\mathrm{H}, \mathrm{Z})$ \\
\hline & D12 & 214D006 & $0-0.5$ & $300(\mathrm{H}, \mathrm{Z})$ \\
\hline & D13 & 214D001 & $0-0.5$ & $280(\mathrm{H}, \mathrm{Z})$ \\
\hline & D14 & 214D012 & $0-0.5$ & $110(H, Z)$ \\
\hline & D15 & 214D015 & $0-0.5$ & $250(\mathrm{H}, \mathrm{Z})$ \\
\hline & D16 & 214D040 & $0-0.5$ & $290(H, Z)$ \\
\hline & D17 & 214D014 & $0-0.5$ & $140(H, Z)$ \\
\hline & D19 & 214D003 & $0-0.5$ & $180(H, Z)$ \\
\hline & D20 & 214D018 & $0-0.5$ & $210(H, Z)$ \\
\hline & D21 & 214D005 & $0-0.5$ & $140(\mathrm{H}, \mathrm{Z})$ \\
\hline & D22 & 214D007 & $0-0.5$ & $290(H, Z)$ \\
\hline & D23 & 214D010 & $0-0.5$ & $290(H, Z)$ \\
\hline & D24 & 214D011 & $0-0.5$ & $110(H, Z)$ \\
\hline & D25 & 214D043 & $0-0.5$ & $190(H, Z)$ \\
\hline & D26 & 214D038 & $0-0.5$ & $230(\mathrm{H}, \mathrm{Z})$ \\
\hline & \multirow{2}{*}{ Y01 } & 214Y001 & $0-0.5$ & $460(\mathrm{~J})$ \\
\hline & & 214Y002 & $0-0.5$ & $520(\mathrm{~J})$ \\
\hline & Y03 & 214Y005 & $0-0.5$ & $110(\mathrm{H}, \mathrm{M})$ \\
\hline & \multirow{2}{*}{ Y04 } & 214Y009 & $0-0.5$ & $240(\mathrm{H}, \mathrm{M})$ \\
\hline & & $214 Y 010$ & $0-0.5$ & $240(\mathrm{H}, \mathrm{M})$ \\
\hline & Y27 & 214Y034 & $0-0.5$ & $140(\mathrm{H}, \mathrm{M})$ \\
\hline
\end{tabular}


Table 5-1

Sample Results for COCs at CASs 25-23-01 and 25-23-19

Used To Establish Current Use Restriction

(Page 2 of 2 )

\begin{tabular}{|c|c|c|c|c|}
\hline \multirow{2}{*}{ CAS } & \multirow{2}{*}{$\begin{array}{c}\text { Sample } \\
\text { Location }\end{array}$} & \multirow{2}{*}{$\begin{array}{l}\text { Sample } \\
\text { ID }\end{array}$} & \multirow{2}{*}{$\begin{array}{l}\text { Depth } \\
\text { (ft bgs) }\end{array}$} & \multirow{2}{*}{$\begin{array}{c}\text { TPH (DRO) } \\
\text { PAL } \\
100 \mathrm{mg} / \mathrm{kg}\end{array}$} \\
\hline & & & & \\
\hline \multirow{3}{*}{ 25-23-01 } & & 214Y064 & 4.5 & $580(\mathrm{H}, \mathrm{M})$ \\
\hline & Y29 & 214Y042 & $0-0.5$ & $120(\mathrm{H}, \mathrm{M})$ \\
\hline & Y31 & 214Y044 & $0-0.5$ & $130(\mathrm{H}, \mathrm{M})$ \\
\hline \multirow{9}{*}{ 25-23-19 } & Y33 & 214Y046 & $0-0.5$ & $100(\mathrm{H}, \mathrm{M})$ \\
\hline & E01 & 214E010 & $0-0.5$ & $190(\mathrm{H}, \mathrm{Z})$ \\
\hline & E02 & 214E001 & $0-0.5$ & $290(H, Z)$ \\
\hline & E03 & 214E003 & $0-0.5$ & $150(H, Z)$ \\
\hline & E04 & 214E005 & $0-0.5$ & $140(\mathrm{H}, \mathrm{Z})$ \\
\hline & E08 & 214E002 & $0-0.5$ & $270(\mathrm{H}, \mathrm{Z})$ \\
\hline & E09 & 214E006 & $0-0.5$ & $120(H, Z)$ \\
\hline & E10 & 214E004 & $0-0.5$ & $140(\mathrm{H})$ \\
\hline & E12 & 214E011 & $0-0.5$ & $180(\mathrm{H}, \mathrm{Z})$ \\
\hline \multicolumn{2}{|c|}{$\begin{array}{l}\text { bgs = Below ground surface } \\
\text { DRO = Diesel-range organics } \\
\mathrm{ft}=\text { Foot } \\
\text { ID = Identification }\end{array}$} & & \multicolumn{2}{|c|}{$\begin{array}{l}\mathrm{mg} / \mathrm{kg}=\text { Milligrams per kilogram } \\
\mathrm{PAL}=\text { Preliminary action level } \\
\text { TPH = Total petroleum hydrocarbons }\end{array}$} \\
\hline \multicolumn{5}{|c|}{$\begin{array}{l}H=\text { The fuel pattern was in the heavier end of the retention time window for the analyte of interest. } \\
J=\text { Estimated value. } \\
M=\text { A pattern resembling motor fuel was detected. } \\
Z=A \text { significant fraction of the reported result did not resemble the patterns of the following petroleum } \\
\text { hydrocarbon products: gasoline, JP-4, JP-8, diesel, mineral spirits, motor oil, Stoddard Solvent, and } \\
\text { Bunker C. }\end{array}$} \\
\hline
\end{tabular}

\subsection{Basis for Use Restriction Modification}

The revised FALs associated with the TPH contamination were established based on the PALs of hazardous constituents of TPH diesel described in Section 2.2.2. Hazardous constituents of TPH diesel were not detected in any of the samples at concentrations greater than their respective PALs (NNSA/NSO, 2004c). Therefore, no contaminants are present at this site in concentrations exceeding the revised FALs, and all revised FALs were established at the PAL concentrations.

\subsection{Proposed Modification}

Remove the FFACO UR, associated fencing and postings, and inspection and maintenance requirements from these sites. 


\section{References}

FFACO, see Federal Facility Agreement and Consent Order.

Federal Facility Agreement and Consent Order. 1996 (as amended). Agreed to by the State of Nevada; U.S. Department of Energy, Environmental Management; U.S. Department of Defense; and U.S. Department of Energy, Legacy Management.

NNSA/NSO, see U.S. Department of Energy, National Nuclear Security Administration Nevada Site Office.

U.S. Department of Energy, National Nuclear Security Administration Nevada Site Office. 2004c. Corrective Action Decision Document for Corrective Action Unit 214: Bunkers and Storage Areas Nevada Test Site, Nevada, Rev. 0, DOE/NV--956. August. Las Vegas, NV.

U.S. Department of Energy, National Nuclear Security Administration Nevada Site Office. 2004f. NV/YMP Radiological Control Manual, DOE/NV--11718-079, Rev. 5. Prepared by Bechtel Nevada. Las Vegas, NV.

U.S. Department of Energy, National Nuclear Security Administration Nevada Site Office. 2006a. Closure Report for Corrective Action Unit 214: Bunkers and Storage Areas, Nevada Test Site, Nevada, Rev. 0, DOE/NV-1160. September. Las Vegas, NV.

U.S. Department of Energy, National Nuclear Security Administration Nevada Site Office. 2006c. Industrial Sites Project Establishment of Final Action Levels, Rev. 0, DOE/NV--1107. Las Vegas, NV. 


\section{Library Distribution List}

\section{$\underline{\text { Copies }}$}

U.S. Department of Energy

National Nuclear Security Administration

Nevada Site Office

Technical Library

P.O. Box 98518, M/S 505

Las Vegas, NV 89193-8518

U.S. Department of Energy

Office of Scientific and Technical Information

P.O. Box 62

Oak Ridge, TN 37831-0062

Southern Nevada Public Reading Facility

c/o Nuclear Testing Archive

P.O. Box 98521, M/S 400

Las Vegas, NV 89193-8521

Manager, Northern Nevada FFACO

Public Reading Facility

c/o Nevada State Library \& Archives

100 N Stewart Street

Carson City, NV 89701-4285
1 (Uncontrolled, electronic copy)

1 (Uncontrolled, electronic copy)

2 (Uncontrolled, electronic copies)

1 (Uncontrolled, electronic copy) 